\title{
ESTIMATION OF ECONOMICAL VALIDITY OF USAGE REMOTE OPERATED DISCONNECTORS FOR 110KV SWITCHGEAR SCHEMES FROM OPTIMAL RELIABILITY LEVEL POINT OF VIEW Aleksandrs Lvovs (Riga Technical University - RTU), Anna Mutule (RTU)
}

The paper gives results of technical and economical calculations performed for estimation of validity of usage remote operated disconnectors for commonly used $110 \mathrm{kV}$ switchgears from optimal reliability point of view.

In the paper there is evaluated reliability level for typical $110 \mathrm{kV}$ substations depending on type of disconnectors that are used for $110 \mathrm{kV}$ switchgears. In the paper calculations were performed for 5 typical $110 \mathrm{kV}$ switchgear schemes. To make estimation more deep and precise, reliability level was evaluated for substations with air $110 \mathrm{kV}$ circuit breakers, SF6 $110 \mathrm{kV}$ circuit breakers, and also for substations placed in $110 \mathrm{kV}$ overhead line network (in rural territories) and in $110 \mathrm{kV}$ cable line network (in cities).

In the paper different types of customers with different power supply interruption costs were taken into account. The fact is important, because usage of average customer interruption costs can introduce big error in calculations. Estimation of economical validity of usage remote operated disconnectors for $110 \mathrm{kV}$ switchgear schemes was performed taking into account geographical allocation and shares of electrical energy consumption in countries' electrical energy consumption of Latvian customers. Such approach allowed making estimation of economical validity for $110 \mathrm{kV}$ rural and city substations more precise comparing to situation, when just average values of customer power supply interruption costs are used.

Calculation results showed economical validity of remote operated disconnectors from reliability point of view.

\section{ATTĀLINĀTI VADĀMO 110KV ATDALīTĀJU IZMANTOŠANAS SADALIETAISĒS EKONOMISKĀ LIETDERĪGUMA NOVĒRTĒŠANA NO OPTIMĀLĀ ELEKTROAPGĀDES DROŠUMA LİMEN,A VIEDOKLA Aleksandrs Ļvovs (Rīgas Techniskā universitāte), Anna Mutule (RTU)}

Raksts dod tehniski-ekonomisko aprēķinu rezultātus, kas tika veikti, lai novērtētu attālināti vadāmo atdalītāju izmantošanas lietderīgumu, visbiežāk izmantotajās $110 \mathrm{kV}$ sadalietaisēs no elektroapgādes drošuma viedokḷa.

Rakstā tiek aprēķināts tipveida $110 \mathrm{kV}$ sadalietašu drošuma līmenis atkarībā no tajās izmantojamiem atdalītājiem, kā arī tiek veikta $110 \mathrm{kV}$ attālināti vadāmo atdalītāju izmantošanas ekonomiskās pamatotības novērtēšana raugoties no elektroapgādes drošuma viedokḷa. Lai veiktu pēc iespējas dzị̣āku un daudzpusīgāku attālināti vadāmo atdalītāju izmantošanas lietderīguma novērtēšanu, 110kV sadalietašu drošums tika aprēķināts piecām tipveida sadalietaisēm apskatot tādus variantus: sadalietaisēs ir uzstādīti gaisa $110 \mathrm{kV}$ jaudas slēdži, sadalietaisēs ir uzstādīti elegāzes $110 \mathrm{kV}$ jaudas slēdži, sadalietaises ir pieslēgtas $110 \mathrm{kV}$ gaisvadu tīklam (lauku rajonu apakšstacijas), kā arī tika apskatīts variants gadījumam, kad sadalietaise ir pieslēgta 110kV kabeļu tīklam (pilsētu apakšstacija).

Darba ietvaros tika apskatītas arī dažādas patēētāju grupas, kurām ir atšķirīgas elektroapgādes pārtraukumu izmaksas. Šis fakts ir svarīgs, jo vidējo ar elektroapgādes pārtraukumiem saistīto izmaksu izmantošana var ieviest lielu kḹūu aprēḳinos. Atdalītāju izmantošanas ekonomiskā lietderīguma novērtēšana tika veikta pamatojoties uz Latvijas elektroenerğijas patērētāju ǵeogrāfisko sadalījumu un to patēriņa īpatsvaru kopējā valsts elektroenerǵijas patēriņā. Tāda pieeja l̦āvusi precīzāk novērtēt atdalītāju izmantošanas pamatotību lauku un pilsētas $110 \mathrm{kV}$ apakšstacijās.

Aprēķinu rezultāti parādīja, ka attālināti vadāmo atdalītāju izmantošana ir ekonomiski pamatota no elektroapgādes drošuma viedokḷa.

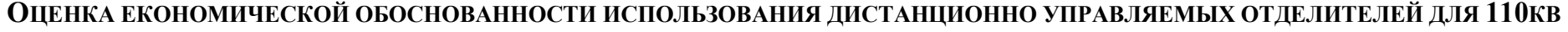 ЭЛЕКТРИЧЕСКИХ РАСПРЕДЕЛИТЕЛЬНЫХ УСТРОЙСТВ С ТОЧКИ ЗРЕНИЯ ОПТИМАЛЬНОГО УРОВНЯ НАДЁЖНОСТИ Aleksandrs Lvovs (Riga Technical University), Anna Mutule (RTU)}

В статье посчитан уровень надёжности типовых 110кВ распределительных устройств в зависимости от отделителей использованных в них, а также произведена оценка економической обоснованности использованя дистанционно управляемых отделителей для 110кВ электрических распределительных устройств с точки зрения оптимального уровня надёжности. Дла проведения более глубокого анализа, уровень надёжности расчитывался для типовых $110 к B$ распределительных устройств: с воздушними 110кВ выключателями мощности, с элегазовыми 110кВ выключателями мощности, для подстанций подсоеденённых к воздушным линиям 110кВ, для подстанций подсоеденённых к кабельным линиям $110 \kappa \mathrm{B}$.

В рамках работы были рассмотренны разные группы потребмтелей с разными затратами при перебоях в электроснабжении. Оценка экономической обоснованности использования дистанционно управляемых отделителей производилась основаваясь на географическое распределение и удельное потредление электроэнергии латвийских потребителей электроэнергии. Такой подход позволил более точно оценить обоснованность использования отделителей для сельских и городских 110кВ подстанций.

Результаты расчётов показали, что использование дистанционно управляемых отделителей является обоснованно с точки зрения надёжности электрообеспечения. 